\title{
Characteristics and Prognosis of Tinnitus after Treatment in Acute Low-Frequency Sensorineural Hearing Loss
}

\author{
Jinsook Kim ${ }^{1,2}$, Eunsung Lee ${ }^{1,2}$, Eui-Cheol Nam³ \\ 'Department of Speech Pathology and Audiology, Graduate School, Hallym University, Chuncheon, Korea \\ ${ }^{2}$ Division of Speech Pathology and Audiology, Research Institute of Audiology and Speech Pathology, College of Natural Sciences, \\ Hallym University, Chuncheon, Korea \\ ${ }^{3}$ Department of Otolaryngology, School of Medicine, Kangwon National University, Chuncheon, Korea
}

\section{급성 저주파수 난청 치료에 따른 이명의 양상 및 예후}

김진숙 ${ }^{1,2} \cdot$ 이은성 $1.2 \cdot$ 남의철 ${ }^{3}$

한림대학교 일반대학원 언어병리청각학과 ${ }^{1}$ 한림대학교 자연과학대학 언어청각학부 - 청각언어연구소 ${ }^{2}$, 강원대학교 의학전문대학원 이비인후과학교실 ${ }^{3}$

\begin{abstract}
Purpose: Acute Low-frequency sensorineural Hearing Loss (ALHL) is characterized by earfullness, tinnitus and hearing loss restricted to the low frequency region. The aim of this study was to investigate the characteristics and prognosis of tinnitus in ALHL. Methods: We investigated tinnitus characteristics with analyzing tinnitograms and studied correlation between tinnitus improvement and hearing recovery of ALHL patients. We classified hearing change after the four weeks of medical treatment applying oral steroid and diuretics into 'complete recovery,' 'partial recovery,' and 'no change.' Degree of tinnitus improvement following the treatment was categorized as 'completely disappeared,' 'partially improved,' and 'persistent.' Results: Among 46 ALHL patients, tinnitus was reported by 34 (74.0\%) patients. After the medical treatment tinnitus completely disappeared in 19 (55.9\%), partially improved in $9(26.5 \%)$, and persisted in $6(17.6 \%)$. Among 26 patients who completed tinnitograms, tinnitus was matched at frequencies $\leq 500 \mathrm{~Hz}$ in $14(53.8 \%)$ and at $\geq 2,000 \mathrm{~Hz}$ in 12 (46.2\%), respectively, forming lower and higher frequency tinnitus groups. Tinnitus completely disappeared or partially improved in 12 (85.7\%) patients with lower frequency tinnitus and in $9(75.0 \%)$ with higher frequency tinnitus. We observed a significant positive correlation between hearing recovery and tinnitus improvement in both lower and higher frequency tinnitus groups $(r=0.74$ and $r=0.62$, respectively). Conclusion: Patients with ALHL may complain the high frequency tinnitus although their hearing loss recently developed in low frequency region. Tinnitus associated with ALHL was successfully treated with applied medications, showing better treatment for lower frequency tinnitus group. Hearing recovery and tinnitus improvement were significantly correlated.
\end{abstract}

Key Words: Tinnitus, Acute, Low-frequency, Hearing loss.

Received: December 1, 2017 / Revised: January 10, 2018 / Accepted: January 11, 2018

Correspondence: Eui-Cheol Nam, Department of Otolaryngology, School of Medicine, Kangwon National University, 1 Gangwondaehak-gil, Chuncheon 24341, Korea

Tel: +82-33-258-2311 / Fax: +82-33-255-8809 / E-mail: birdynec@kangwon.ac.kr

\section{INTRODUCTION}

급성 저주파수 난청(Acute Low-frequency sensorineural Hearing Loss, ALHL)의 정의는 아직 명확하게 확립되지 않아 다양한 진단 기준이 있다(Abe, 1982; Fuse et al., 2002; Junicho et al., 2008; Kitajiri et al., 2002). 1982년에 ALHL을 독립된 질
환으로 처음 보고한 Abe는 저주파수 대역 즉, $125,250,500$ $\mathrm{Hz}$ 에서 평균 $35 \mathrm{~dB}$ 이상의 청력 손실이 있는 경우만을 $\mathrm{ALHL}$ 로 정의하였으나, 최근에는 2011년 일본 후생노동성이 제시한 정의가 보다 널리 사용되고 있다. 이 정의에 따르면 이충만감과 이명의 증상과 함께 저주파수들 $(125,250,500 \mathrm{~Hz})$ 에서 청력 역치의 합이 $70 \mathrm{~dB}$ 이상이면서 고주파수 $(2,000,4,000,8,000$ 
$\mathrm{Hz}$ )의 역치의 합은 $60 \mathrm{~dB}$ 이하인 경우를 "명확한(definite) ALHL”이라고 하였다. ALHL의 유병률은 10만 명당 40 60명 정도이며, 난청과 함께 이충만감, 자가강청, 이명 등을 주로 호소 한다. ALHL에 대한 약물 치료는 주로 내림프수종을 겨냥한 이 뇨제, 돌발성 난청에 사용되어 온 스테로이드제 혹은 둘을 함께 투여하는 치료법으로 이루어지며 이에 따른 청력 회복 효과는 75 92\%로 우수한 편이지만 재발률도 9 47\%로 높은 편이다 (Jung et al., 2016; Kawashima et al., 2006; Morita et al., 2010). ALHL은 청력 손실이 갑자기 발생한다는 공통점에서 이전에 는 돌발성 난청(idiopathic sudden sensorineural hearing loss) 의 일부로 분류되기도 하였으며, 어지럼증이 동반되면 메니에르 병(Ménière's disease)과 아주 유사한 양상이 되므로 ALHL 진 단 시 어지럼증은 제외 기준이 된다(Conlin \& Parnes, 2007; Mattox \& Simmons, 1977). ALHL이 상기한 두 질환들과 다 른 점은 다음과 같다. 첫째, ALHL은 돌발성 난청과 달리 저주 파수 영역에만 국한된 청력 손실을 보이며 32 65\% 환자에서 저절로 증상이 회복된다. 둘째, ALHL은 청력 손실의 정도에 따라 $10 \%$ 내외가 나중에 메니에르병으로 진행될 수 있으나 ALHL 단계에서는 어지럼증을 호소하지 않는다. 다만 전기 와 우도 검사에서 많은 ALHL 환자가 내림프수종(endolymphatic hydrops)을 시사하는 소견을 보여 두 질환 사이에 기전을 공유 하는 연관성이 보고된 바 있다(Fuse et al., 2002). 셋째, 돌발성 난청은 중년 이상의 남성에서 유병률이 높으나 ALHL은 젊은 여성에서 유병률이 높고, 치료 후 돌발성 난청의 청력 역치가 ALHL에 비해 높기 때문에 돌발성 난청보다 ALHL의 예후가 더 좋은 것으로 알려져 있다(Yoshida et al., 2017).

ALHL의 치료법과 치료에 의하거나 혹은 자연적으로 나타난 청력 회복에 대한 예후는 여러 차례 조사된 바 있으나(Fuse et al., 2002; Jung et al., 2016; Morita et al., 2010), ALHL 환자의 약 $80 \%$ 에서 이명이 동반된다는 보고만 있을 뿐(Jung et al., 2016) ALHL에 흔히 동반되는 이명의 양상과 치료 후의 예후나 특히 청력 회복과 이명 개선의 연관성 등에 대한 상세한 연구 는 거의 이루어진 바가 없다. 일반적으로 갑자기 발생한 난청의 경우 청력의 회복과 이명의 개선이 대개 상관성이 있다고 알려 져 있으나, 때로는 청력의 회복에도 불구하고 이명 증상이 남아 고통을 호소하는 경우가 있으며, 청력이 호전되지 않더라도 청 각장애에는 잘 적응하는 반면 이명에 적응하지 못하는 경우도 흔하다. 따라서 본 연구에서는 ALHL에 동반된 이명의 특징과 약물치료에 따른 청력 회복과 이명의 변화를 조사하고 그 둘 사이의 상관성을 알아봄으로써 임상적으로 중요한 정보를 제 공할 수 있는 계기가 될 수 있을 것으로 생각된다.

\section{MATERIALS AND METHODS}

2016년 1월부터 12월까지 강원대학교 이비인후과 외래로 내 원하여 ALHL로 진단받은 46명(평균 $49 \pm 14.5$ 세, 범위 16 76 세)의 의무기록 및 검사 소견 등을 후향적으로 분석하였다. 치 료 전후의 이과적 증상에 대한 문진, 외이도와 고막 상태에 대한 이내시경과 중이검사 소견, 순음청력검사와 이명도검사 (tinnitogram) 등의 결과를 분석하였다. 본 연구는 강원대학교 병원 생명의학연구윤리위원회의 승인을 받아 시행되었다(승인 번호 201708003).

연구 대상의 선정에는 2011년 일본 후생노동성에서 정의한 '명확한 ALHL'의 기준을 적용하였다. 즉, 내원 2주 이내에 발생 한 이충만감, 이명, 난청, 자가강청 등을 호소하며, 세 개의 저주 파수 $(125,250,500 \mathrm{~Hz})$ 청력 역치의 합이 $70 \mathrm{~dB}$ 이상이고, 세 개의 고주파수 $(2,000,4,000,8,000 \mathrm{~Hz})$ 의 역치의 합이 $60 \mathrm{~dB}$ 이하인 경우를 연구 대상으로 포함하였다. 문진에서 어지럼증 을 호소하거나 이경검사 혹은 고막 운동성 검사에서 비정상 소 견을 보인 경우는 제외하였다. 총 46명의 ALHL 환자 중 환자 의 주관적 보고에 따라, 이명 증상을 동반한 34명의 ALHL 환 자의 약물치료 전후 청력 역치와 이명 변화를 분석하였다.

ALHL의 약물치료로써 스테로이드제(메틸프레드니솔론 하 루 $48 \mathrm{mg}$ ) 혹은 이뇨제(하이드로클로로티아지드와 이소소르 비드액 하루 각각 $25 \mathrm{~mL}$ 와 $40 \mathrm{~mL}$ )를 2주간 경구 투여하였다. 2주 치료 후 청력검사에서 $125,250,500 \mathrm{~Hz}$ 의 청력이 $20 \mathrm{~dB}$ 이하로 청력이 완전히 회복된 경우에 치료를 종료하였고, 청력 이 완전히 회복되지 않은 경우엔 처음에 처방하지 않은 다른 약 물인 스테로이드제나 이뇨제를 교대로 2주간 추가로 투여하며 치료 개시 4주 후 치료를 종결하였다. 최종적인 치료 결과는 치 료 종결 후 청력 회복의 정도에 따라 저주파수인 $125,250,500$ $\mathrm{Hz}$ 모두에서 청력 역치가 $20 \mathrm{~dB}$ 이하이면 '완전 회복(complete recovery, $\mathrm{CR})$, 완전 회복은 아니지만 치료 전 저주파수 청력보 다 평균 $10 \mathrm{~dB}$ 이상 회복된 경우를 "부분적 회복(partial recovery, PR),' 이 두 경우에 해당하지 않는 경우를 '변화 없음 (no change, NC)'으로 분류하였다.

이명을 느낀다고 기술한 34 명 중 이명도를 시행한 26 명의 이 명 주파수를 분석하였고, 약물치료에 따른 이명의 개선 정도에 따라 이명이 완전히 사라진 경우를 '완치(completely disappeared),' 아직 남아 있으나 확실하게 크기가 감소하였다고 보 고한 경우를 '부분적 개선(partially improved), 이명이 변화가 없거나 오히려 악화되었다고 보고한 경우를 '지속(persisted)'으 로 분류하여 치료에 따른 이명의 변화 양상을 분석하였다.

통계분석은 SPSS version 18.0 (SPSS Inc., Chicago, IL, USA) 소프트웨어를 이용하였다. 전체 ALHL 환자 46명에 대 
한 치료 전후의 청력 변화가 유의한지는 변수가 정규분포이므 로 대응표본 $\mathrm{t}$ 검정(paired t test)을 시행하여 조사하였다. 이명 도검사를 시행한 26명에 대해 이명 주파수가 $500 \mathrm{~Hz}$ 이하인 저 주파수 이명군과 $2,000 \mathrm{~Hz}$ 이상인 고주파수 이명군으로 나누 어 각 군별로 이 경우는 비정규분포이므로 비모수적 통계분석 방법인 윌콕슨 부호 순위 검정(Wilcoxon signed rank test)을 시행하여 치료 전후의 청력을 비교하였다. 또한, 청력 회복과 이 명 개선 사이의 상관관계를 확인하기 위해 Spearman 상관성 분석을 시행하였다. 모든 통계분석의 유의성 판정은 유의수준 0.05 를 기준으로 하였다.

\section{RESULTS}

ALHL의 증상이 나타난 기간은 내원 시까지 평균 $7.2 \pm 4.5$ (1 14)일이었다. 전체 46명 중, 여성이 20명 남성은 26명이었고, 오른쪽 귀 21명(45.7\%) 왼쪽 귀 25명(54.3\%)이었다. 이명을 호 소한 경우는 34 명(74\%)이었고 이충만감을 호소한 경우가 33 명 (72\%)이었다.

청력의 회복 정도를 치료 전후 기도 청력의 역치를 비교한 결
과(Figure 1), 치료 전 저주파수(125, 250, $500 \mathrm{~Hz})$ 의 청력 역치 의 합은 평균 $109.6 \mathrm{~dB}$ 이었고, 치료 후엔 평균 $55.5 \mathrm{~dB}$ 로 통계 적으로 유의한 변화를 보였다 $(p<0.05)$. 반면, 치료 전 고주파 수 $(2,000,4,000,8,000 \mathrm{~Hz})$ 의 역치의 합은 평균 $47.2 \mathrm{~dB}$, 치료 후엔 $44.8 \mathrm{~dB}$ 로 의미 있는 변화를 보이지 않았다 $(p>0.05)$.

이명도검사를 시행한 26명 중 이명 주파수가 $500 \mathrm{~Hz}$ 이하인 군은 14 명(53.8\%)이며, 그중 $250 \mathrm{~Hz}$ 에서 9명으로 가장 높은 빈 도를 보였다. 이명 주파수가 $2,000 \mathrm{~Hz}$ 이상인 군은 12 명(46.2\%) 이며, 그중 $8,000 \mathrm{~Hz}$ 이상이 9명이었다(Figure 2).

이명을 느끼는 환자 34명에서 치료 후 청력 회복의 빈도는 완전 회복이 25명(73.4\%), 부분적 회복이 4명(11.8\%), 변화 없음 이 5명(14.7\%)으로 나타났다. 이명 개선의 빈도는 완치가 19명 (55.9\%), 부분적 개선이 9명(23.5\%)이었고, 이명이 지속된 경우 가 6명(20.6\%)이었다(Figure 3).

청력 회복의 정도에 따라 분류하여 각 군별로 이명의 개선 정도를 살펴보았다(Figure 4). 청력이 완전히 회복된 $\mathrm{CR}$ 군 25 명 중 이명이 완치된 경우가 19 명, 부분적으로 개선된 경우가 4 명, 지속된 경우가 2명이었고, 이명이 완치된 19명은 모두 CR군 에서만 관찰되었다. 이명이 완치되었거나 부분적으로 개선된 경

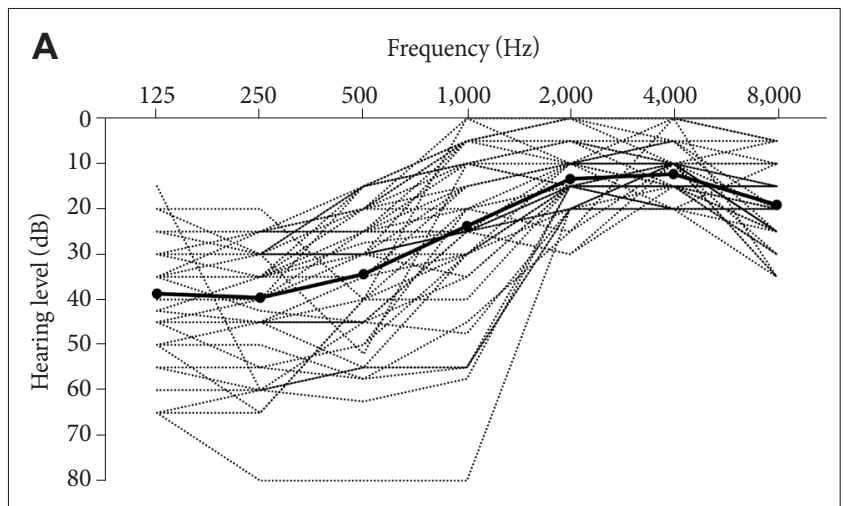

B Frequency $(\mathrm{Hz})$

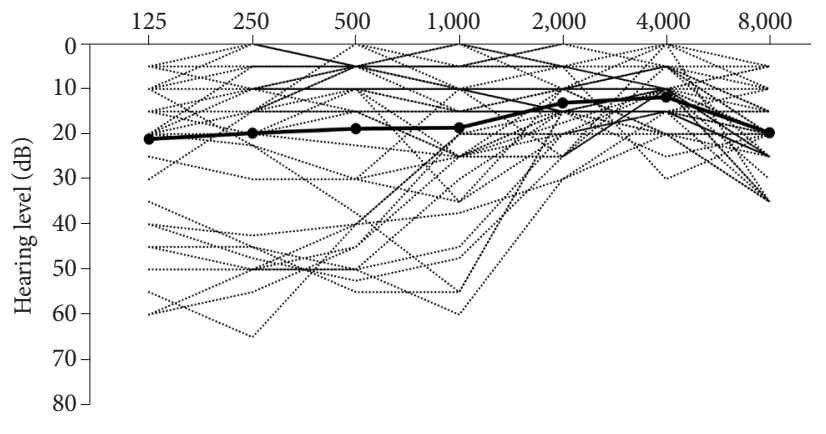

Figure 1. Pure-tone hearing thresholds of 46 ears before $(A)$ and after $(B)$ medical treatment. The hearing thresholds at the lower frequencies show significant improvement when compared to those of the higher frequencies. The solid lines indicate the mean hearing thresholds.

Figure 2. The distribution of the matched tinnitus frequencies. The matched tinnitus frequencies at $500 \mathrm{~Hz}$ or lower and at $2,000 \mathrm{~Hz}$ or higher were revealed at fourteen patients $(53.8 \%)$ and twelve patients $(46.2 \%)$, respectively.

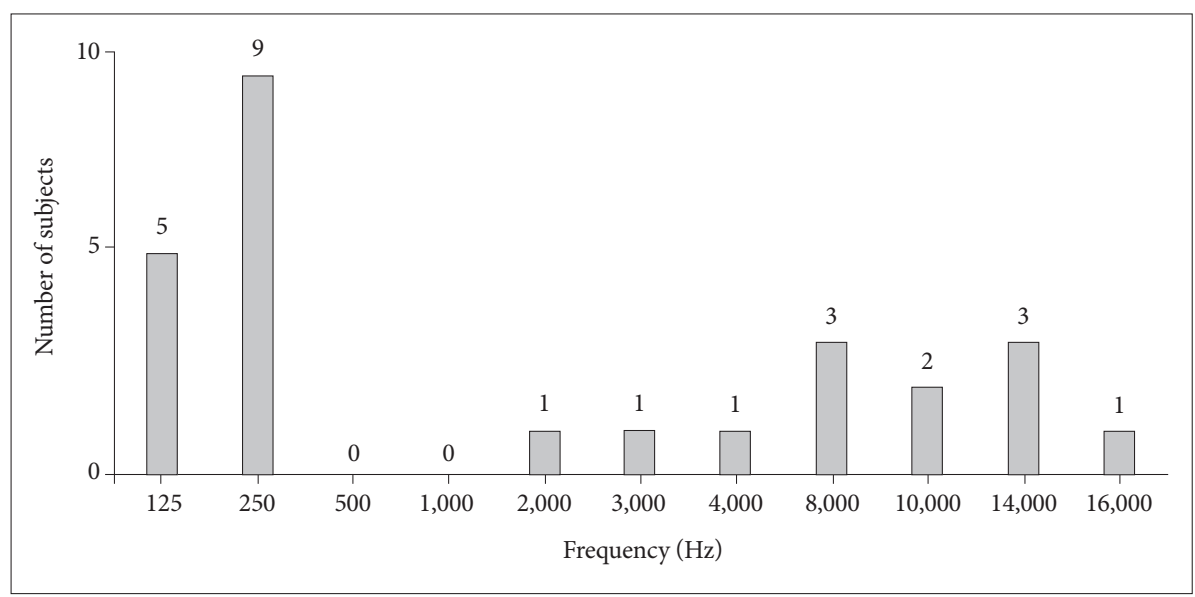




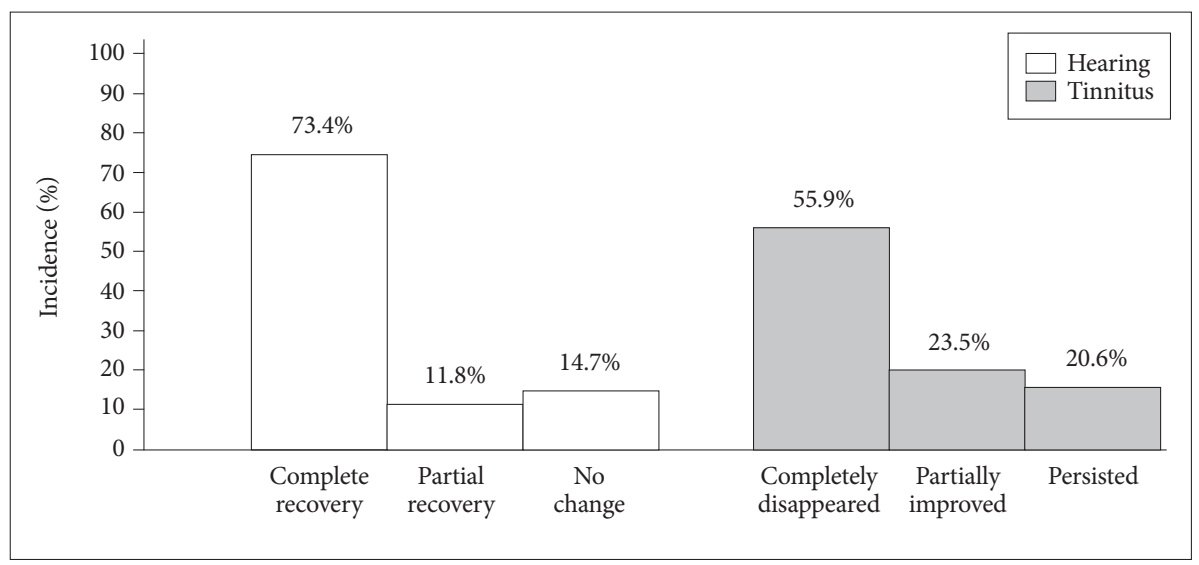

Figure 3. Incidencies of hearing recovery and tinnitus improvement after medical treatment in patients with Acute Lowfrequency sensorineural Hearing Loss ( $\mathrm{n}$ $=34$ ). The combined ratios of complete and partial recovery of hearing $(85.2 \%)$ and improvement of tinnitus (82.4\%) were similar.

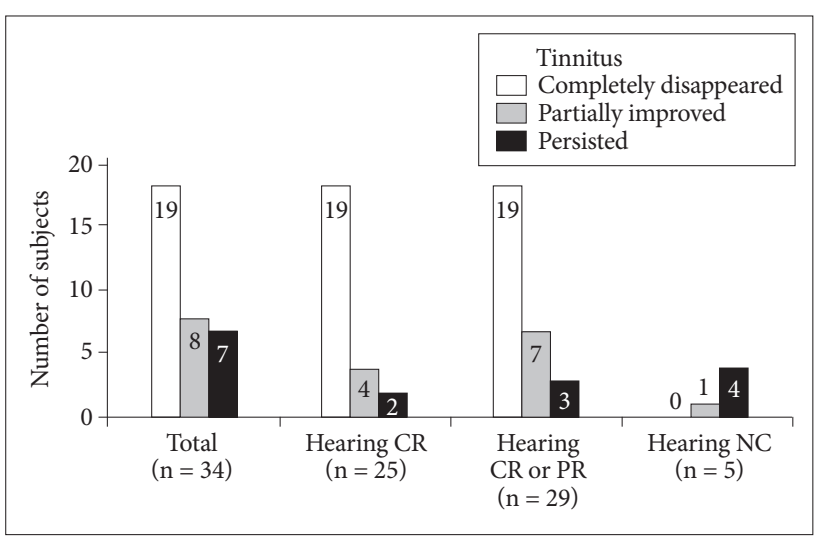

Figure 4. Incidences of tinnitus improvement according to the degree of hearing recovery. The tinnitus improvement when defined as 'completely disappeared' and/or 'partially improved' was observed in $26(89.7 \%)$ among 29 of the hearing recovery group which was composed with both groups of CR and PR of hearing. Whereas the tinnitus improvement was observed in only $1(20.0 \%)$ among 5 of the hearing 'NC' group. CR: complete recovery, PR: partial recovery, NC: no change.

우를 합쳐 이명의 개선으로 해석할 때, $\mathrm{CR}$ 군 25 명 중 23 명 (92.0\%)에서 이명 개선 효과가 나타났다. 이에 비해 청력이 부 분적으로 회복된 PR군 4명과 청력에 변화가 없었던 $\mathrm{NC}$ 군 5명 중에서 이명이 개선된 경우는 각각 3명(75.0\%)과 1명(20.0\%)에 서 이명이 개선된 것으로 나타났다. 따라서 청력이 회복된 경우 로 분류할 수 있는 $\mathrm{CR}$ 군과 $\mathrm{PR}$ 군을 합친 29명 중 이명이 개선 된 경우는 26명(89.7\%)으로, 청력이 전혀 회복되지 않은 $\mathrm{NC}$ 군 과 큰 차이를 보였다.

치료 종료 후 청력이 완전히 회복된 경우가 이명이 완치된 경 우보다 약 $17 \%$ 많은 것으로 나타났고 부분적으로 청력이 회복된 경우는 이명이 부분적으로 개선된 경우보다 $15 \%$ 적었으며 청력 에 변화가 없거나 이명이 지속된 경우의 빈도는 비슷한 것으로 나타났다. 청력의 완전 회복과 부분적 회복을 합친 회복률은 $85.2 \%$ 였고, 이명의 완치와 개선된 경우를 더한 이명 개선율은 $82.4 \%$ 로 서로 비슷한 빈도를 보였다.
저주파수 이명군 $(500 \mathrm{~Hz}$ 이하)과 고주파수 이명군 $(2,000 \mathrm{~Hz}$ 이상)을 비교할 때, 치료 전, 저주파수 $(125,250,500 \mathrm{~Hz})$ 청력 역 치의 합은 각각 $121.8 \mathrm{~dB}$ 과 $105 \mathrm{~dB}$ 이었고, 고주파수(2,000, $4,000,8,000 \mathrm{~Hz}$ ) 역치의 합은 각각 $55.5 \mathrm{~dB}$ 과 $41.7 \mathrm{~dB}$ 로 저주 파수 청력과 고주파수 청력 모두 두 군 사이에 통계적으로 유 의한 차이를 보이지 않았다 $(p>0.05)$. 치료 후 저주파 청력 역 치의 합은 각각 $48.6 \mathrm{~dB}$ 과 $48 \mathrm{~dB}$, 고주파수 역치의 합은 각각 $47.7 \mathrm{~dB}$ 과 $47.1 \mathrm{~dB}$ 로 역시 저주파수 청력과 고주파수 청력 모두 두 군 간 통계적으로 유의한 차이를 보이지 않았다 $(p>0.05)$. 따라서 이명이 저주파수이거나 고주파수이거나 상관없이 청력 의 초기 손실 및 회복에 있어 차이가 없는 것으로 나타났다. 즉, 환자가 느끼는 이명 소리의 높낮이는 치료 전 혹은 후의 청력 의 양상과는 무관한 것으로 조사되었다.

청력의 회복과 이명의 증상 개선에 대한 상관성 분석에서도 통계적으로 유의하게 높은 상관계수 $(\mathrm{r}=0.68, p<0.05)$ 를 보여 두 변수 사이의 높은 상관성이 있음을 확인할 수 있었다. 저주 파수 및 고주파수 이명군에서 이명이 완전히 사라지거나 개선 된 빈도는 각각 14명 중 12명(85.7\%)과 12명 중 9명(75.0\%)으로 저주파수 이명군에서 이명이 개선된 빈도가 더 높았다(Figure 5). 두 군에서 청력의 회복과 이명의 개선 사이의 상관성을 살펴 보면 저주파수 이명군에서는 CR 11 명 중 이명의 완치는 8 명 (72.7\%), 개선은 3 명(27.3\%)이었고, PR군 1명은 이명이 개선되었 으며, $\mathrm{NC}$ 군 2명은 모두 이명이 지속된 경우로 나타났다(Figure $5 \mathrm{~A})$. 상관성 분석에서도 저주파수 이명군에서 청력의 회복과 이명의 개선 사이에 유의하게 높은 상관계수를 보였다 $(\mathrm{r}=0.74$, $p<0.05)$. 한편 고주파수 이명군에서는 $\mathrm{CR}$ 군 8 명 중 이명의 완치는 6명(75.0\%), 개선과 지속은 각각 1명이었다. $\mathrm{PR}$ 군 1명은 이명이 개선되었으며, $\mathrm{NC}$ 군 3명 중 1명(33.3\%)에서만 이명이 개 선되었고, 2명(66.7\%)은 이명이 지속된 경우로 나타났다(Figure $5 \mathrm{~B})$. 고주파수 이명군에서도 저주파수 이명군보다 낮지만 청력 의 회복과 이명의 개선 사이에 역시 유의한 상관성이 있는 것으 

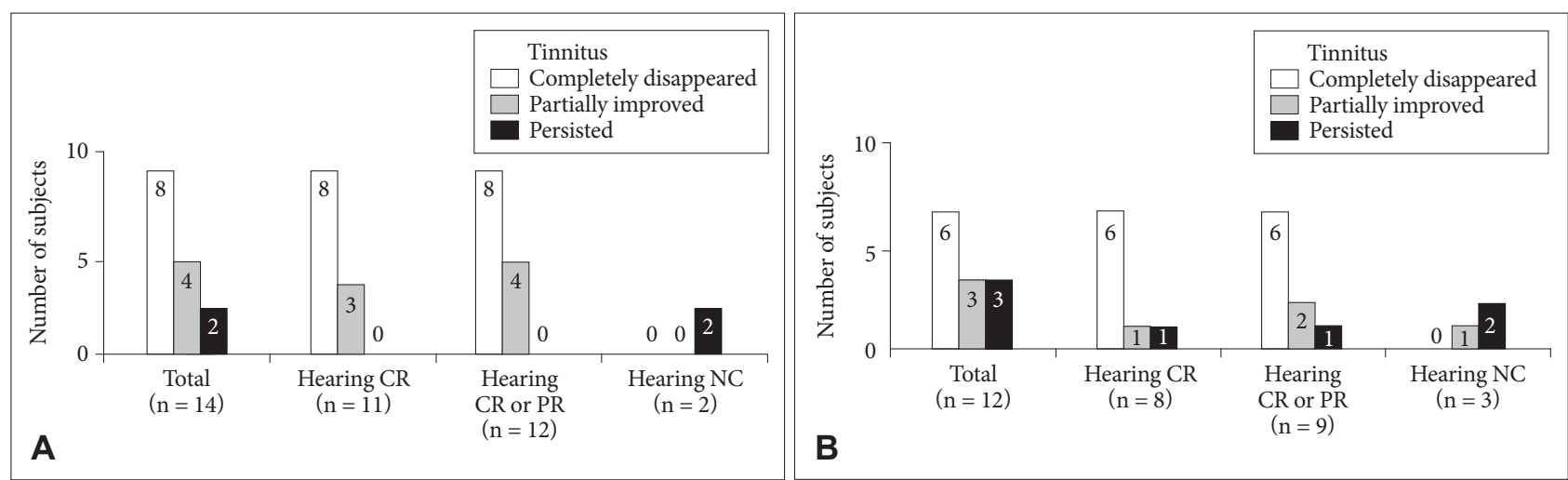

Figure 5. Incidences of tinnitus improvement according to the degree of hearing recovery in lower (A) and higher (B) tinnitus frequency groups. For both groups, tinnitus was observed as 'completely disappeared' out of the only groups of 'CR' of hearing. CR: completely recovery, PR: partial recovery, NC: no change.

로 조사되었다 $(\mathrm{r}=0.62, p<0.05)$. 저주파수 이명의 경우 $\mathrm{CR}$ 군 과 PR군에 속했던 12명 전원(100\%)이 이명이 완치 혹은 개선되 었고, 고주파수 이명을 호소한 경우엔 $\mathrm{CR}$ 군 혹은 PR군에 속했 던 9명 중 8명(88.9\%)의 이명이 완치 혹은 개선되었다.

\section{DISCUSSIONS}

본 연구에서 ALHL 환자의 $74 \%$ 가 이명을 호소하였고 약물 치료 후 $82.4 \%$ 의 이명이 호전을 보였으며 이는 청력 회복과 유 의한 상관성을 보였다. 이와 같이 청력의 회복에 따라 이명이 회 복되는 경우는 급성 감각신경성 난청 질환들에서 공통적으로 관찰되는 현상이라 할 수 있다. 돌발성 난청에서 이명은 약 54.4 80.0\%에서 동반된다고 보고되고 있으며(Chen et al., 2015; Kim et al., 2016; Nosrati-Zarenoe et al., 2007), 그중 Chen 등 의 돌발성 난청 연구에서 청력은 $51.2 \%$, 이명은 $52.1 \%$ 에서 호전 되어 청력과 이명이 서로 비슷한 회복률을 보였고, Kim et al. (2016)은 돌발성 난청 79명 환자 중 77.2\%가 이명을 호소하였고 치료 후 이명이 완전히 사라진 $26 \%$ 의 환자는 모두 청력이 완전 히 회복되었던 경우라고 보고하면서 청력의 회복이 이명의 개 선에 아주 중요한 요소라고 지적하였다.

ALHL 환자의 이명에 대한 선행연구로서 Jung et al.(2016) 은 ALHL 환자 50명 중 약 80\%가 이명을 호소하였고, 경구 스 테로이드 단독 투여 후 청력의 완전 혹은 부분적 회복은 $82.8 \%$, 이명의 완전 혹은 부분적 개선은 $69.0 \%$ 로 보고하였다. 본 연구 의 이명 개선율 $82.4 \%$ 에 비해 개선 빈도가 낮았던 이유는 아마 본 연구에서 스테로이드와 이뇨제를 번갈아 투여한 것에 비해 스테로이드 단독 투여의 치료 효과가 낮았기 때문일 것으로 생 각된다. 실제로 다른 ALHL 연구에서 스테로이드 단독 투여는 $75.5 \%$, 이뇨제 단독 투여는 $75.0 \%$, 두 가지를 병용 투여할 경우 엔 $91.3 \%$ 에서 청력이 부분 혹은 완전히 회복된다고 보고한 선
행연구와 같은 맥락으로 해석할 수 있다(Morita et al., 2010). 일반적으로 난청에 동반된 이명은 청력 역치가 가장 저하된 주파수에서 나타난다고 알려져 있다. 소음성 난청의 경우 이명 주파수의 평균은 $4,200 \mathrm{~Hz}$ 였고, 돌발성 난청의 경우 난청이 최 대인 주파수가 $5,600 \mathrm{~Hz}$ 인 그룹에서 이명 주파수는 4,600 Hz 였고, 저주파 소음에 노출된 경우 발생한 이명의 평균 주파수 는 평균 960 Hz이었다(Kim et al., 2012; Kim et al., 2016; Ueberfuhr et al., 2017). 본 연구 결과에서 저주파수 이명군의 이 명 개선율은 $85.7 \%$ 로 고주파수 이명군의 $66.7 \%$ 보다 높고 청력 회복과 이명 개선의 상관계수도 0.74 로 고주파수 이명의 0.62 보 다 더 높게 나타난 점은 치료 약물이 저주파 영역에서 더 효과 적으로 작용한 것으로 생각할 수 있다.

본 연구에서 이명의 주파수를 분석한 결과 $46.2 \%$ 의 높은 빈 도로 $2,000 \mathrm{~Hz}$ 이상의 고주파수 이명을 호소하였다. 그 원인으 로 가장 먼저 환자가 이명 주파수 매칭이 부정확한 경우를 생 각할 수 있으나 문진 당시 저주파수 이명에 대한 표현으로 '냉 장고 돌아가는 소리', '엔진 소리, '웅웅대는 소리' 등을 보고하는 반면, 고주파수 이명에 대한 표현으로는 '삐' 소리, '매미 소리' 등을 뚜렷하게 기술한 경우가 상당수 있었으므로 주파수 매칭 의 착오로 이를 모두 설명하기는 어렵다. 다른 가능성으로서 본 연구에서 적용한 ALHL 정의는 고주파수 역치의 합을 $60 \mathrm{~dB}$ 까지 허용하므로 ALHL 발병 이전에 존재하던 경도의 고주파 수 난청이 혼재되어 있을 가능성이 크며 실제로 일부 환자들은 $4,000 \mathrm{~Hz}$ 와 $8,000 \mathrm{~Hz}$ 에서 $35 \sim 40 \mathrm{~dB}$ 의 역치를 보인 경우들이 있었다. 이런 경우 ALHL 발병으로 인한 저주파 청력의 갑작스 러운 소실은 환경소음을 차단하는 효과로 나타나 고주파수 대 역의 소리에 대한 집중도가 높아져 발병 이전에는 듣지 못하던 고주파수 이명을 새롭게 듣게 된 것으로 추측할 수 있다. ALHL 치료 후 고주파수 이명의 개선 역시 치료로 인해 저주파수 대역 의 청력이 회복되어 환경음 청취가 다시 가능해지면서 고주파 
수의 이명이 이전처럼 차폐되던 상태로 돌아간 것으로 생각된 다. 또 다른 가능성으로 난청의 영역과 상관없이 나타나는 이명 의 주파수 범위를 생각할 수 있다. 예를 들어, 저주파 난청을 주 로 보이는 메니에르병에서 이명의 주파수가 다양하게 나타날 수 있다는 연구 보고는 이러한 논리를 뒷받침한다. 87 명의 메니

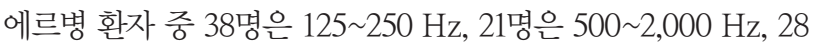
명이 3,000 8,000 Hz의 이명 주파수를 보여 $32.2 \%$ 가 3,000 $\mathrm{Hz}$ 이상의 고주파수 이명을 호소한다고 보고한 연구(Zhang et al., 2016)와 청력 손상이 있는 주파수 영역과 이명이 출현하는 주파수 영역과의 상관성이 높지 않다는 다른 연구 결과들도 있

다(Chiossoine-Kerdel et al., 2000; Pan et al., 2009).

본 연구는 46명의 ALHL 환자에 대하여 후향적으로 의무기 록을 검토하였기 때문에 다음과 같은 몇 가지 제한점을 가지고 있다. 검사 공간과 시간적 제약으로 인해 이명을 호소했던 34명 중 26명에 대해서만 이명도 검사를 시행하였으므로 연구 대상 의 숫자가 적은 편이라는 점과 $\mathrm{ALHL}$ 의 정의를 세 개 고주파 수 청력 역치의 합을 기준으로 적용하였으므로 한두 개의 고주 파수에 존재하는 청력 손실과 관련된 이명이 포함될 수 있다는 점이다. 따라서 향후의 연구에서 고주파수 청력에 대해 보다 엄 격한 기준을 적용한다면 본 연구의 결과와는 다른 양상의 이 명 주파수 분포가 나타날 가능성이 있다는 문제점이 있다. 차 후 전향적 연구를 통해 본 연구의 제한점을 보완하고, 본 연구 결과와 관련된 추가적인 검증과 고실 내 스테로이드 주사요법 및 여러 이명 치료 방법에 따른 이명의 변화 등을 새로이 조사 해 볼 필요가 있을 것으로 생각한다.

중심 단어 : 이명·급성·저주파수·난청.

\section{Acknowledgments}

이 논문은 2016년도 과학기술정보통신부의 재원으로 한국연구재 단 바이오 의료기술개발 사업의 지원을 받아 수행된 연구임(2016M3 A9F1941022).

\section{REFERENCES}

Abe, T. (1982). Acute sensorineural hearing loss in low tone frequencies. Otolaryngology (Tokyo), 54, 385-392.

Chen, Y., Wang, Z., Wang, Z., Chen, D., Chai, Y., Pang, X., et al. (2015). Targeted next-generation sequencing in Uyghur families with non-syndromic sensorineural hearing loss. PLoS One, 10(5), e0127879.

Chiossoine-Kerdel, J. A., Baguley, D. M., Stoddart, R. L., \& Moffat, D.A. (2000). An investigation of the audiologic handicap associated with unilateral sudden sensorineural hearing loss. The American Journal of Otol- ogy, 21(5), 645-651.

Conlin, A. E. \& Parnes, L. S. (2007). Treatment of sudden sensorineural hearing loss: II. A Meta-analysis. Archives of Otolaryngology--Head and Neck Surgery, 133(6), 582-586.

Fuse, T., Aoyagi, M., Funakubo, T., Sakakibara, A., \& Yoshida, S. (2002). Short-term outcome and prognosis of acute low-tone sensorineural hearing loss by administration of steroid. ORL; Journal for Oto-Rhino-Laryngology and Its Related Specialties, 64(1), 6-10.

Jung, A. R., Kim, M. G., Kim, S. S., Kim, S. H., \& Yeo, S. G. (2016). Clinical characteristics and prognosis of low frequency sensorineural hearing loss without vertigo. Acta Oto-Laryngologica, 136(2), 159-163.

Junicho, M., Aso, S., Fujisaka, M., \& Watanabe, Y. (2008). Prognosis of lowtone sudden deafness-does it inevitably progress to Meniere's disease? Acta Oto-Laryngologica, 128(3), 304-308.

Kawashima, Y., Sato, H., Okamoto, M., Nakashima, T., Ihara, K., \& Kitamura, K. (2006). Epidemiological study of acute low-tone sensorineural hearing loss in Kanagawa and Iwate Prefectures. Audiology Japan, 49(4), 373-380.

Kim, N. J., Park, H. O., Sim, C. S., Lee, C. R., Kwon, Y. J., \& Lee, J. H. (2012). The characteristics of tinnitus and hearing threshold: In workers with noise induced hearing loss from a hospital setting. Korean Journal of Occupational and Environmental Medicine, 24(4), 431-440.

Kim, T. S., Yoo, M. H., Lee, H. S., Yang, C. J., Ahn, J. H., Chung, J. W., et al. (2016). Short-term changes in tinnitus pitch related to audiometric shape in sudden sensorineural hearing loss. Auris Nasus Larynx, 43(3), 281286.

Kitajiri, S., Tabuchi, K., Hiraumi, H., \& Hirose, T. (2002). Is corticosteroid therapy effective for sudden-onset sensorineural hearing loss at lower frequencies? Archives of Otolaryngology--Head and Neck Surgery, 128(4), 365-367.

Mattox, D. E. \& Simmons, F. B. (1977). Natural history of sudden sensorineural hearing loss. The Annals of Otology, Rhinology, and Laryngology, $86(4$ Pt 1), 463-480.

Morita, S., Suzuki, M., \& Iizuka, K. (2010). A comparison of the short-term outcome in patients with acute low-tone sensorineural hearing loss. ORL; Journal for Oto-Rhino-Laryngology and Its Related Specialties, 72(6), 295299.

Nosrati-Zarenoe, R., Arlinger, S., \& Hultcrantz, E. (2007). Idiopathic sudden sensorineural hearing loss: Results drawn from the Swedish national database. Acta Oto-Laryngologica, 127(11), 1168-1175.

Pan, T., Tyler, R. S., Ji, H., Coelho, C., Gehringer, A. K., \& Gogel, S. A. (2009). The relationship between tinnitus pitch and the audiogram. International Journal of Audiology, 48(5), 277-294.

Ueberfuhr, M. A., Wiegrebe, L., Krause, E., Gürkov, R., \& Drexl, M. (2017). Tinnitus in normal-hearing participants after exposure to intense lowfrequency sound and in Ménière's disease patients. Frontiers in Neurology, 7, 239.

Yoshida, T., Sone, M., Kitoh, R., Nishio, S. Y., Ogawa, K., Kanzaki, S., et al. (2017). Idiopathic sudden sensorineural hearing loss and acute low-tone sensorineural hearing loss: A comparison of the results of a nationwide epidemiological survey in Japan. Acta Oto-Laryngologica, 137(sup565), S38-S43.

Zhang, Y., Liu, B., Wang, R., Jia, R., \& Gu, X. (2016). Characteristics of the cochlear symptoms and functions in Meniere's disease. Chinese Medical Journal (Engl), 129(20), 2445-2450. 